\title{
Battle in the Boardroom: A Discursive Perspective
}

\author{
Wilson Ng (Judge Institute of Management Studies, University of Cambridge) \\ and \\ Christian De Cock (School of Business and Economics, University of Exeter)
}

\begin{abstract}
This article examines the centrality of storytelling in achieving managerially relevant outcomes, with a focus on the in-situ performance context of corporate storytellers influencing one another. The Ricœurian concept of speech act, capturing both the intentionality of organisational discourse and the social context of its production and reception, implicitly guided our research effort. The article has at its core a story of how senior organizational officers exploited the volatile circumstances of a major public offer in Singapore. By looking at the social construction of narratives in their many fragments we come to see how a key protagonist carves out a position of power. The efficacy of his performances can be seen to be dependent upon the effective use of poetic tropes and the receptiveness of listeners to particular Chinese archetypal relationship-driven themes. In crafting our story we use multiple texts which were produced in and around two case organizations. As such we offer a carefully constructed collage, a mixture of production and reproduction, sticking closely to forms of communication that key organizational actors used to plan, enact and interpret their actions and those of others. Whilst our story offers insights to readers with an interest in organizational discourse, corporate governance and Asian management practices, we refrain from imposing an authoritarian interpretation that insists on identifying with the intentions of the authors.
\end{abstract}

\section{Contact: Christian De Cock (C.De-Cock@exeter.ac.uk)}




\section{Battle in the Boardroom: A Discursive Perspective}

\section{Preamble}

Valentine's Day 1995 was a watershed in Singapore corporate history. On this day, Antony, Singapore's oldest company, launched a hostile takeover bid for Cleo, a "homegrown success story" which was one of Singapore's best known companies ${ }^{1}$. The hostility of Antony's bid surprised the local market; analysts could not recall the last hostile takeover. The brazenness of Antony's pursuit caught public attention: Cleo's balance sheet was over twice the size of Antony's and she employed eight times the number of Antony's staff.

To gain public support, Antony executed a meticulous public relations program which centered on the appointment of a new chairman for Cleo. Antony's board of directors nominated a local Chinese entrepreneur with great public stature for this role. Given his public standing, the chairman was supposed to strengthen market credibility for the takeover. At the same time, Antony's directors expected him to cement control of Cleo on Antony's behalf. They thought they could control the chairman because he had served Antony loyally for many years.

Initially the new chairman seemed to reward the faith invested in him as he began an “extensive program to review and restructure [Cleo's] operations (Cleo Announcement, 12/04/1995)." But appearances deceived. Behind a facade of corporate unity, Cleo's new chairman initiated a power struggle to seize control of Cleo. He eventually took exclusive, personal control of Cleo and left Antony, the majority shareholder, without an effective voice in running Cleo.

The public were never aware of any "battle in the boardroom". Instead, public statements painted an official story of change as well organized and professionally managed with a successful outcome never in doubt. However, beneath this level of public perception several other storylines gave conflicting accounts of how Cleo's restructuring was 
progressing. These various storylines form the crux of our investigation as they point to the importance of discursive performances given by key protagonists in carving out positions of power.

\section{Framing the study}

"The basic technology of organization is... a technology of narrative, as well as a technology of production. The contested terrain of organizations is seen as a terrain of meaning (March, 1996, p. 286).”

Our study can be firmly located within the "narrative mode" (Bruner, 1986, 1990) or "narrative paradigm" (Fisher, 1985). We take a distinctive position which locates us alongside a range of other writers who are interested in narrative as a way of expressing practical knowledge and understanding organizational processes (Barrett et al., 1995; Czarniawska, 1997; Keenoy et. al, 1997; Rhodes, 2000; Watson and Harris, 1999). Whereas in the logico-scientific mode of knowing an explanation is achieved by recognizing an event as an instance of a general law, or as belonging to a certain category; narrative knowledge tells of human projects and their consequences as they unfold over time, thus capturing the nuances of event, relationship and purpose that are often obscured in the traditional academic abstraction process (Czarniawska, 1998). Attention to time, motives and human agency help to preserve the situational particularity missing from propositional statements favored by the logico-scientific mode (Pentland, 1999; Riessman, 1993). From a narrative viewpoint the traditional research interest in organizations as distinct entities gives way to a focus on organizations-embedded-inpractices (Tsoukas and Cummings, 1997). It allows for the centrality of human beings as creators and interpreters of meaning in an organization and for narration and storytelling as valid and valued parts of organization studies (Wicks and Freeman, 1998).

In this narrative turn the field of organization studies has mirrored developments in philosophy and social theory. Scholars such as MacIntyre (1985), Rorty (1991) and Taylor (1985) have been instrumental in promoting narrative as the basic and essential genre for the characterization of human actions. Although more precise definitions have 
been suggested and debated, for our present purposes it is sufficient to think of narratives and stories as interchangeable terms, used here in the same sense that the terms are used in ordinary conversation ${ }^{2}$ (cf. Boyce, 1996; Rappaport, 1993). The terms "narrative" and "story" generally refer to thematic, sequenced accounts that convey meaning from implied performer/author to implied audience/reader (Barry and Elmes, 1997). In successfully identifying and understanding what organizational actors are doing, we always move towards placing a particular episode in the context of a set of narrative histories, both in terms of the individuals concerned and of the settings in which they act (MacIntyre, 1985). Thus we can conceive of narratives and stories as underpinning the never-ending construction of meaning in organizations.

Weick (1995) pointed out that researchers are often handicapped when they try to make sense of organizational life, because their skills at using narratives for interpretation are not tapped by most traditional models of organization. Yet most organizational realities are based on narration ${ }^{3}$. Thus the adoption of a narrative approach to knowledge in, and about, organizations may increase the relevance of organizational knowledge produced by academics. As Pentland suggested: “[T]he significance of narrative data lies not just in their richness and near universal availability, but in the fact that they are the same kind of data that organizational members use to plan, enact, interpret, and evaluate their own actions and those of others... Thus when we analyze narrative, we are starting with raw material that is central to the cognitive and cultural world of our subjects (Pentland, 1999, p.716)."

Many well-known studies from the 1980s conceived of organizational stories or narratives as artifacts forever petrified in the organizational reality "out there" waiting to be "collected" (Boland and Tenkasi, 1995). In the 1990s the field moved on to question these rather synthetic accounts based in "stories-as-objects" theory. The emphasis shifted to "stories-in-context" research, with a focus on both the in-situ performance context of storytellers influencing one another, and the historical context of local embeddedness of "micro" stories in wider "macro" stories (Boje, 1998). Boje (1991), in his study of an office supply firm, challenged the stories-as-objects tradition in collecting tape recordings 
of stories told in-situ, and defined stories as partial, fragmented, and extended across multiple conversations involving many actors. In partial tellings, the collective combines to tell the fuller story, but across time and in different spaces. The implication is that researchers need to track stories across settings and capture its invocation even where few story features are visible: to look at glosses, terse tellings, and shifts in the telling of events to construct different power alignments. In Boje's (1995) study of the Disney corporation, plots, meanings and characterizations change over time depending on whose viewpoint (old and new management, workers, journalists, etc.) stories were being told as well as revised. Czarniawska (1997) in her various studies on the transformation of organizations in the Swedish public sector, shows these organizations to be complex and dynamic webs of narratives. Just as in Boje's work, narratives are viewed as constitutive of particular organizational realities, rather than mere measures of something else. Czarniawska makes the reader aware that "[A]lthough 'narratives on organizations', that is, organization studies, are usually stylized in the 'only true story' format, 'narratives in organizations', tales told in the field, are manifold and often ironic (p.26)."

In the above studies the analysis of stories (Boje's preferred term) and narratives (Czarniawska's preferred term) is pursued as a means of revealing the indeterminacy of organizational experiences (cf. Keenoy et al., 1997). By looking at the social construction of narratives in their many fragments, with various performances telling multiple stories, these narratives are now seen to be fragmentary, intertextual (referring to narratives outside themselves), situated and strategic in nature (Pentland, 1999). Whilst earlier theorists tried to read into stories existing "out there", the focus in these studies is on the dynamics of situated and contextualized storytelling. They take as object of investigation the story and its performance, not simply the content to which language refers. If we were to study narratives abstracted from their performance we would fail to see the connection between language, power, and social structure (Burkitt, 1998). Czarniawska's and Boje's studies are also characterized by their attention to the ownership of organizational stories. Understandings are seen to be quite disparate, negotiated, and hegemonic - hegemonic in the sense that some voices, interpretations, and stories are more privileged than others in subtle ways. As Boje et al. (1999) suggest: "Storytelling theory is all about who is in 
control of the story - who is shaping and influencing the story (p.354)." It is not about whose story is best, but who has the power to make a story stick as one that others will choose to live by or in. The power dimension of storytelling is implicit in the term "discourse", defined as a historically contingent body of regularized practices of language that are condoned by a particular community (Casey, 1995; Prior, 1997). Indeed "we are all 'effects' of the power of discourse, we all move from one discursive network to another, always producing power relations (Calás and Smircich, 1999, p.657-658)."

In crafting our research story we pick up on the themes of "performance" and "discourse" in the operational concept of discursive performances. We see discursive performances as exercises in power, with power defined as the capacity to extend hegemonic reach by suppressing or overwhelming competing accounts such that one's own interpretation dominates (Brown, 2000). The concept is thus meant to capture both the hegemonic and performative aspects of linguistic actions. These actions are rooted in the sequences, patterns, and meanings that stem from exchanging verbal and nonverbal messages (Putnam et al., 1996) and may include orally transmitted narratives, the authoring of organizational and institutional texts, and even selective silences. Following Czarniawska, we will treat texts as actions ("strictly speaking, material traces of such, but they both result from and provoke further action"), and actions as texts: "Actions, especially institutionalized actions, produce texts; texts not only 'fix' other actions- their production and interpretation assume actions (Czarniawska, 1999, p.11).” Even when fixed as text, organisational discourse retains many of the properties associated with speech acts, remaining closely bound to its authorial context and relying for its meaning on attributions of instrumental intent (Heracleous and Hendry, 2000). Senior organizational actors will be seen to use a range of storytelling performances in the sense of producing narratives with simple but resonant plots, involving skill, entailing risk, and aiming to entertain, persuade, and win over various listener-stakeholders (cf. Gabriel, 2000). We will look towards identifying conventionalized, patterned organizations of performances and will explore how performances are interpreted and evaluated by the performers' intended audience (cf. Coffey and Atkinson, 1996). 


\section{Crafting the story}

\section{Empirical foundations}

"[R] esearchers who want to use stories as a research instrument must be prepared to sacrifice at least temporarily some of the core values of their craft and adopt instead a rather alien attitude towards their subjects and their texts. They must rid themselves of the assumption that quality data must be objective, reliable, accurate, etc. and must be prepared to engage personally with the emotions and the meanings that reside in the text... At the same time, researchers must not lose sight of the relation between stories and facts: facts are not dissolved by stories but re-created through them (Gabriel, 2000, p.135-136).”

Most narratives do not just lie around in organizational situations nor do documents wait to be related. They have to be "authentically crafted and configured" (Golden-Biddle and Locke, 1997, p.19) from a variety of sources. In our research story we weave together direct field observation, interviews and systematic collection of textual data to unravel the contextual import of organizational stories, and the voices of these stories (Boje, $1995 ; 1998)$. As such we offer a collage - a mixture of production and reproduction that every reading and writing necessarily entails (Czarniawska, 1999) - with the authorship of different pieces distinctly attributed. This does not mean that we try to efface our role or claim innocence from the representational force that we bring to this text. A good deal of selectivity stands behind any author's decisions about what details to include, what organizing concepts to use, what events to highlight, and so forth (Van Maanen, 1998). Understandings that researchers present must ultimately be construed as factive fictions crafted from numerous sources and methods, influenced by the availability and quality of different materials, and designed to please both the researchers and the researchers' audiences (Barry, 1996; Watson, 2000).

In crafting our research story we have been particularly influenced by a growing body of text based research (Gephart, 1978, 1993; Brown, 2000; Brown and Jones, 2000). Organizational texts can be seen as contrived rhetorical products that contain implicit power dimensions, and which stifle potentially competing or contradictory storylines, 
thus serving hegemonic and legitimation functions. The texts produced in and around the two case companies that we collected and analyzed comprise: complete board minutes of Antony and Cleo covering an eighteen month period, inter-office memoranda, company announcements and prospectae, one officially released interview transcript, commentary from the Singapore press, and stockbroking analysts' reports. These texts are complemented by texts we generated ourselves: the transcripts of two personal interviews with senior executives and a variety of retrospective fieldnotes.

We concentrated on the viewpoints of senior managers because of the specific boardroom environment in which the related events took place, an environment in which only certain company representatives, principally directors, were allowed access. In this context, board minutes are of particular importance in providing structure and substance to our study because of their monopoly of meaning; aspects that are named and actions that are recognized in the minutes gain legitimacy and importance (Oakes et al., 1998). What gets documented as well as ignored can reveal "the most fundamental struggle for power and control" (Phillips and Hardy, 1997, p.171). This is not to suggest that board minutes provide a "true" representation of the underlying organizational reality they are supposed to reflect. Rather, we see them as material instruments in a power construction process. In forcing a particular closure on events and situations which are interpretively open ended, power is constructed, sustained and reproduced. Board mintues are certainly not selfexplanatory. As outsiders, researchers often lack contextual experience and are not therefore in a position to read insightfully into the apparently uncomplicated communicative intent of a formalized set of board minutes. Contextual experience is provided here by the first author who was a Cleo Group Executive Director as well as a non-executive director on Antony's main board throughout the restructuring process and beyond. As one of Cleo's most senior executive officers he participated in all board meetings and subcommittee meetings of the board covering the material period.

\section{Analysis of the textual data}

We approached our exploration of the textual sources in two distinct stages. Firstly, we scanned the textual sources for stories, including snippets of stories which might be 
embedded in "terse" format (Boje, 1991, p.115). We used the first author's knowledge of depicted events to pick out snippets which, taken together, appeared to support a particular storyline although extracts in themselves did not necessarily constitute an intelligible story. We accordingly filled in the blanks of terse, apparently incomplete stories by bridging snippets of stories across time (mainly represented by different sets of board minutes) and across the two organizations. The second stage of our approach involved collating, reducing and coding identified micro-stories. We first sketched a "start list" of stories under narrative headings as we studied the texts and then developed the various storylines, building up additional stories through subsequent re-readings. We highlighted interesting parts of texts with various codes which in one reading did not fit any particular storyline and returned to them after finishing reading the set of texts in its entirety. The codes reflected the level of stories which we identified from any one reading. From our narrative headings we built up various tables of narratives. For each narrative, we considered its relative "dominance" by gauging how key stakeholders of Antony and Cleo reacted to the respective stories.

Concentrating on narrative headings (rather than, for instance, grouping texts by dates or by identified actors) was our means of "bridging" our textual data. This was because we knew there was always a follow-on concerning an identified story across time periods (given that Cleo's restructuring was a stop-start process over an extended period) and across the corporate operating space of both Antony and Cleo (given that the two companies were closely related and that they therefore shared common stakeholders). So a story developed in one company would invariably also appear in textual sources belonging to the other company. We decided not to use text display/coding computer software because the language of our main sources was extremely terse and there was usually little or no explanation to things or people referred to. The reason was that the private papers were written for an informed, internal staff audience and accordingly a suitably informed interpreter was required to draw meaning out of extant texts.

In developing our research story we needed several annotated readings to break the surface level of the official texts which were carefully couched in "neutral" language. We 
read into the multiple versions of organizational reality in order to reduce the importance of phenomena named as "important" in the official stories, whilst reconstructing other aspects that were ignored as unimportant. Thus, for example, whilst we noticed the "official story" of incremental, controlled change during the early transition stage of Cleo's restructuring, we paid less attention to this storyline in our study of the texts. Instead, given our awareness of the impending power struggle, we focused on seeking evidence of internal, unpublicized stories involving Cleo's chairman, and on trying to make sense of these unpublicized stories in relation to later restructuring stages when the chairman's narrative became clearly prominent. We therefore took less notice of gauging the accuracy of texts as a faithful record of what was actually said than of showing how the sources provided a consistent storytelling perspective which directors made sense of and on which basis they then developed appropriate action strategies.

\section{Introducing the story}

\section{Company history}

Antony was originally a colonial trading house. It became quoted on the Singapore Stock Exchange in 1979. The company's core competence was in providing mechanical and electrical engineering expertise for building projects. Antony also harbored a fastgrowing property development division which sought to reinvest its earnings in new property projects. It shot to prominence when it led the development of several landmark projects in the emerging markets of Indochina and Indonesia.

Antony had a payroll of about 300 full-time employees who were mostly engineers or technical support staff. However, despite its entrepreneurism, Antony lacked the breadth of skills required to expand in the building industry; hence its interest in Cleo.

Cleo's expertise complemented Antony's. Since its founding in the 1970s Cleo had become one of Asia's largest civil engineering contractors, and it gained a quotation in 1981. Cleo had an international reputation for alternative engineering solutions and it won numerous public awards with its ability to develop and apply innovative techniques. By the time of Antony's bid, Cleo had developed a capability for turnkey design and 
build which was a prestigious and lucrative market niche. This capability boosted Cleo's value as a takeover target.

Cleo employed over 2,000 staff including 400 civil engineers which made it the largest private employer of engineers in Singapore. What Cleo lacked was operating efficiency to match its technical competence; hence its apparent suitability as Antony's partner.

\section{Synopsis of the takeover}

Antony had long held a significant shareholding interest in Cleo and had consistently shown that it wanted to play a bigger part in Cleo's future. However, Cleo's board of directors spurned Antony's advances. Antony became frustrated: it had invested hugely in Cleo but received only one board seat. Antony's directors soon hardened to the view that Antony had to take control of Cleo in order to protect its investment.

Antony's takeover offer lasted three weeks over February and March 1995. As Antony had already secured over $40 \%$ of Cleo's shares prior to announcing the takeover, the offer process was a formality. Immediately following closing of the offer, all of Cleo's existing board members resigned and Antony nominated a fresh slate of directors, including the first author. The new board got down to reviewing Cleo's operations and there followed a “stagnant" period of about six months. Suddenly in September 1995, Cleo's chairman called a special board meeting at which he proposed the appointment of three senior board directors to head up Cleo. He told Cleo's board that he had handpicked all three executives and that they had already started work in the company.

The appointment of the three new executives coincided with Cleo's announcement of its first operating loss as a quoted company. This loss seemed to usher in a period of radical corporate restructuring which affected all operating areas in Cleo. The radical nature of restructuring was epitomized by a new corporate logo and a new mission statement. Above all, the new chairman took personal charge of Cleo, and external stakeholders including Antony no longer had access to any information about Cleo except through channels designated by Cleo's chairman. 
By mid-1996 Cleo had substantially completed its internal restructuring. Staff resignations declined and Cleo's share price stabilized. However, the apparent calm dissolved on $8^{\text {th }}$ June 1996 when press articles reported the Cleo chairman's proposed "Golden Parachute". This so-called "Parachute" was a contractual clause which formed an integral part of the chairman's new service contract; the "Parachute" would open automatically if the chairman's contract were prematurely terminated, in which event Cleo would be obliged to pay its chairman S\$7,000,000 (circa US\$4,350,000 at exchange rates prevailing at the time). While initial press reports repeated the facts of the “Golden Parachute” based on Cleo's own announcements, one powerful press columnist published a scathing commentary of the chairman's motives for his "Golden Parachute". Further adverse press commentary followed. Antony now faced severe pressure from its banks who threatened to cut their financial backing.

Antony scheduled a board meeting to discuss the looming crisis. Cleo's chairman was unable to attend, but the meeting took place nonetheless. At the meeting several of Antony's directors voiced their unhappiness with Cleo's chairman. Critically, however, Antony's board unanimously resolved to continue backing the chairman. Given the public perception that Antony had always acted in concert with Cleo's chairman, Antony's directors were caught in an impasse: regardless of whether they now disapproved of the chairman, they were unable to disassociate themselves publicly from his behavior.

\section{Principal Dramatis Personae}

Antony's chairman, an Indonesian Chinese, was the single largest shareholder of Antony and had bought into Antony in 1990. He had turned around Antony and built it up into a diversified operation which formed the cornerstone of his business empire. Antony's chairman was appointed Cleo's deputy chairman following the takeover. Cleo's new chairman, a Singaporean Chinese, was a well known entrepreneur who had received multiple honors from the Singapore government. He was a director of a number of quoted companies worldwide and sat on government statutory committees. 
Antony's MD, a chartered accountant, was a close associate of Antony's chairman and had been Antony's MD since its takeover in 1990.

Antony's ED was a Member of the Singapore Parliament and a qualified accountant. Although he headed up Antony's finance and administration, Antony's directors did not nominate him to the board of Cleo.

Antony's audit committee chairman was an eminent lawyer who took over the chairmanship of the audit committee from the first author shortly after the takeover. He was originally nominated to Antony's board of directors by Cleo's new chairman. The first author was appointed by Cleo's board as “Group Executive Director" heading up Treasury \& Corporate Development. He was also a non-executive director of Antony throughout Cleo's restructuring and he remains a non-executive director of Antony. His is the main voice narrating the "Battle in the Boardroom" .

\section{Battle in the Boardroom}

We present Cleo's post-takeover restructuring in three sequential periods: a transition period of about six months immediately following the takeover in March 1995, when nothing significant changed; an implementation stage of about nine months from September 1995, when almost every part of the company's business and operations experienced some change; and the outcome of reengineering stage from mid-1996, when Cleo declared that "changes in organization, systems, and procedures have been successfully implemented (Cleo 1996 Annual Report, p.5)." This temporal organization is based on the "plot" of the evolving power struggle which we used to assign meanings to various texts and related events. Following Bruner $(1986,1990)$ and Pentland (1999, p.712-716) we ensure that our research story displays various distinct features of "good" narratives. Above all, we have structured our story sequentially. We identify each of our focal characters and try to preserve the polyvocality of their stories (identifiable narrative voice). At the end of our story we elaborate on the evaluative context in which various discursive performances take place. 


\section{The post-takeover transition stage}

In the post takeover transition phase, we identify three distinct narratives from the texts we reviewed. The most dominant narrative proved to be the official story which Cleo's management put out through Cleo's communications department. This narrative tells of an incremental change process controlled by Cleo's management. By “dominant” we mean that this story seemed to be able to attract stakeholders both within and outside Cleo who took for granted its veracity and acted, spoke, and wrote on the basis of Cleo's announcements and other public information. In contrast, Antony's public story tried to present a confident public image of its efforts to manage Cleo's restructuring. We designated Antony's discourse as "weaker" because it had far less discernible impact on its intended audience. We can also discern at this stage an emerging internal discourse building up the reputation of Cleo's chairman. There were still other identifiable narratives during this stage, although they appear less structured. The existence of a multiplicity of narratives before restructuring got under way seemed to reflect the social dynamics of an organization-in-flux in which powerful corporate individuals jostled for position against one another.

-- Insert Table 1 about here --

Building on his public reputation, Cleo's chairman began a series of discursive performances in board meetings at both Antony and Cleo. The purpose of the performances seemed to be to win over the support of directors, particularly on Antony's board. The kind of support that Cleo's chairman sought appeared to be intensely personal in that he probed for ways to develop a sense of personal loyalty to himself. By developing a "taken for granted" sense of power he aimed to assuage doubts about his proposed actions.

One of the first such actions was to establish a general understanding among Antony's directors to "leave it to him" to manage Cleo without interference from Antony. In the following extract, the Cleo chairman's fellow directors warmed to his apparent sagacity 
and Antony's audit committee chairman ended up endorsing the Cleo chairman's reputation:

“[Audit Committee Chairman] said he supported [the Cleo Chairman's] view... [the Cleo Chairman] was way beyond our experience in managing turnaround situations and if anything goes wrong it would be left to [Cleo's chairman] to pick up the pieces. As [Cleo's Chairman] has all the credentials for the job, [Antony's ED] said the least the directors could do was to offer him the board's full support for a reasonable length of time... [Audit Chairman] supported this view and said the directors should leave it to [Cleo's Chairman] and not discuss strategy at this stage (Antony board minutes, 04/1995, emphasis added)."

There seemed no better endorsement of the Cleo chairman's reputation than a statement from the most senior independent director of Antony which brought to the board's attention its own inexperience in managing turnaround situations. The continuing vote of confidence in Cleo's chairman given by Antony's audit committee chief assuaged any doubts directors had about the chairman's actions: for the time being, Antony's ED was prepared to give him the benefit of any doubt and "to offer the chairman [his] full support". In retrospect, this bought vital time for Cleo's chairman to push through his own agenda; having secured the support of Antony's board, he could focus his attention on his chosen task without needing to divert his energies elsewhere.

In contrast, the performances of Antony's chairman at board meetings were unimpressive. As an Indonesian, he seemed socially disadvantaged in that some board members held a preconceived view of Indonesians as “short-term traders", while Cleo's chairman was credited with a "long-term" investment outlook. This prejudice was reflected in the way Antony's chairman struggled for the attention of his board colleagues:

"[Antony] chairman said we must continue with the original plan to move Cleo forward. He was against giving any card blanch [sic.] to run Cleo. He said that as we invested millions we should... take out the fruits of our labor as soon as possible... [Cleo's chairman] said we must take a long-term view and proposed that we first look at Cleo's business and try and understand the business before acting. [Antony] chairman said this was just his point and said we should immediately start looking into Cleo from the inside as originally planned (Antony board minutes, 08/1995)." 
The Antony chairman's position was further undermined by deprecating rumors about his amateurish ("John Wayne”) style of management:

"OK, now I remember after they heard the [Indonesian] chairman was taking over, [Divisional Directors] made [computer] printouts and they put this John Wayne cowboy picture of [Antony's chairman] on the tables. I think they put [up] six or seven pictures on a stand and one lunchtime some of the boys took out a water gun and they all tried [in turn] to shoot down all the pictures in one go. Yeah it was all a prank [but] $I$ didn't see it I only heard about it... no no I can't remember who spread this rumor (Interview with Cleo's Finance Controller, 15/02/1999)."

Most damaging, however, to the Antony chairman's reputation was the performance of Antony's own directors who aired their support of Cleo's chairman rather than of their own. This support weakened the story put out by Antony's board that Antony's managers, rather than Cleo's, were directing the course of restructuring because it appeared that they did not believe in their own ability to control the restructuring. As the two chairmen fought, Cleo's line managers received cross signals about the restructuring. Predictably, they took a "wait-and-see" attitude, and the restructuring process stalled.

\section{Implementation stage}

The first operating loss in Cleo's public history reported in September 1995 signaled a marked change in its re-engineering efforts. As this loss was recorded on significantly increased turnover, Cleo's board of directors felt there was an urgent need for significant internal changes. For the chairman the loss seemed to inspire a greater effort to gain exclusive, personal control of Cleo. This was evidenced in various powerful, discursive performances at Cleo board meetings: at a specially convened board meeting on $14^{\text {th }}$ October 1995, Cleo's chairman declared, in the presence of Antony's chairman, that he had "handpicked" three new senior managers to run Cleo, and after a brief summary of each manager's C.V., he asked the new directors immediately to join the same board meeting. In fact, the three new managers had already started work in Cleo several days previous to the board meeting: the board minutes revealed that organizational changes had already been implemented, apparently on the Cleo chairman's personal authority, and he reported the fait accompli in a discursive tour de force:

“[Cleo's] chairman reported that [named CEO] and [named 2 Dy CEOs] had been approached to fill respective vacancies. All 3 had accepted the offers made to them and have been introduced to Heads [of Departments]... chairman said that he would like to propose the names of the 3 executives as board 
Directors... chairman said that it was now necessary to bite the bullet with the internal restructuring. There was no time to waste because we had already lost a lot of opportunities in the market. He said any restructuring should not take more than 3 or 4 months to complete and in all other companies he had been involved with the speed of restructuring was essential [to its success]. In company X [controlled by Cleo's chairman], he had brought in a new MD well before the start of restructuring and the new chief had been very professional... chairman said that if only we had been allowed to do this the company would have saved a lot of time and we all know time is money (Cleo board minutes, 14/10/1995, emphasis added)."

After the chairman's command performance, the minutes do not reflect substantial further discussion; board participants, including the participant author, were stunned into silence. By late 1995 Cleo's chairman began dictating the pace and nature of change, and other directors and managers appeared to be trying to keep up with his restructuring plan. The chairman's handpicked managers appeared to control the input to various narratives on his behalf, and other managers and employees were found to be jockeying for position within narratives traceable to the chairman.

At the same time as he was conducting board-level performances to win over fellow directors, the Cleo chairman was also trying to win the support of the company's line managers, and through them rank-and-file employees. This was an important part of the Cleo chairman's strategy, because by winning over line managers Antony could not exert any direct influence over the company's operations. The Cleo management's various staff offers can be interpreted as attempts ("carrots") to try and gain support from line managers. But there was also a hidden agenda of continuing control of the same line managers which was evidenced by the "stick" of heightened expenditure policy and operating restrictions.

The following table shows three separate and contrasting narratives during the implementation stage. As in the transition stage, these narratives competed for the attention of Cleo's most important stakeholders.

-- Insert Table 2 about here -- 
Cleo's success in telling a good story which stuck in the minds of public stakeholders can be gauged by continuing favorable press reports ${ }^{4}$. Secondly, Cleo's chairman continued to enjoy the unanimous support of Cleo's board of directors. Unlike Antony's board minutes during this period, Cleo's board minutes seemed to display a sense of urgency to complete Cleo's restructuring. Antony's board in response could only applaud Cleo's actions: "The board supports Cleo's restructuring efforts which should now be completed as soon as possible (Antony board minutes, 29/09/1995)". While still trying to maintain a public appearance that they were in control of Cleo, Antony's senior directors developed a sense of helplessness at their inability to influence Cleo. Antony's loss of control was the Cleo chairman's gain, although his quest for power continued to be couched in language which suggested that he was working primarily to benefit Cleo:

“[Cleo's chairman] told the board... [that] the new Cleo managers were loyal to the company... he had full confidence that they will carry out their duties in the best interest of the company (Antony board minutes, 14/10/1995)."

\section{Outcome of change stage}

Cleo's "spin doctors" continued to impress the story of a successful restructuring:

"The [Cleo] Group has been restructured to focus on five main business areas... [the consequence of which is that its] operating divisions have been able to serve customers with improved efficiency and quality... [the Group] won a record number of projects [in 1996] (Cleo 1997 Annual Report and Accounts, p.14)." By now the Cleo chairman had succeeded in gaining exclusive control of the company. This seemed clear from Cleo's public actions: her operators started tendering for many projects in partnership with the chairman's private organization and without Antony's involvement. This contradicted Antony's publicized aim at the time of takeover to facilitate a "synergy" of activities between the two companies (cf. Antony Takeover Circular, 02/1995). Despite their frustration, Antony's managers felt helpless to act. An indication of how deeply Antony felt about its failure to work with Cleo was that years after the relationship had ended, the failure continued to unsettle Antony's MD:

"We are supposed to be one group together synergizing remember? ...I paid millions for the company [Cleo] and I [got] chickenfeed from you (Interview with Antony’s MD, 22/12/1998).”

As market analysts forecasted Cleo's return to profitability, the press ran an article charging that Cleo had "sweetened the service contract for [its] chairman with a generous 
golden parachute of up to $\mathrm{S} \$ 7,000,000$ ". It was "the first time such a device has been used by a public listed company in Singapore (“The Straits Times", 08/06/1996, p.40).” It appeared that Cleo's chairman did not consult Antony's directors about his new service contract - despite Antony having to pay for the chairman's parachute if they were to fire him (cf. Antony board minutes, 17/06/1996).

By this stage the Cleo chairman's story had fused with Cleo's "public story". Cleo's chairman had successfully mobilized the active consent of Cleo's stakeholders in developing a storyline which his audience took for granted as the dominant storyline. None of his opponents were able to dominate a particular discourse in the way Cleo's chairman $\mathrm{did}^{5}$. By comparison, Antony's chairman proved to be an ineffective storyteller: his performances failed to persuade his listeners to back his story. The most important group of listeners were Antony's bankers who started voicing their unhappiness that Antony had lost control of its largest investment:

“[Antony's MD] brought to the board's attention... Antony might be adversely affected and Antony might not be able to obtain refinancing facility to carry on... the scenario of receivers being called in cannot be ruled out (Antony board minutes, 17/06/1996)."

Antony's story became usurped by a public story about Antony's inability to play a meaningful role in Cleo:

"Who can stop [Cleo's chairman]? ...Antony can as the company's biggest shareholder, and the fact that it hasn't so far done so does not reflect well on any of those involved in this unsavory episode ("The Straits Times", 08/06/1996)".

-- Insert Table 3 about here --

Antony's continuing dissatisfaction with being excluded from Cleo's management reached an extreme point when Antony's directors, including those who had previously supported Cleo's chairman, summoned an emergency board meeting to censure him. Antony's board minutes of $17^{\text {th }}$ June 1996 revealed that Antony had been consistently denied management information about Cleo despite repeated requests, and the blockage resulted in a scenario in which Cleo seemed to be dictating not only its own future but that of Antony as well: 
Antony's MD : "You know you were there so why are you asking me all these things. It was such a big deal to get anything from you. I just didn't understand all these games you people were playing. It was the real thing you know, no fooling around. My banks went crazy and I looked to you for info [about the golden parachute] and I kept asking you to get the info. You know my banks and everybody said stop. But you refused to stop (long pause). I felt so helpless because I couldn't do anything and I remember I kept calling and calling [you] and remember what you said to me what (pause) you didn't have it. So I thought why the **** am I keeping you there?"

Interviewer (Wilson $\mathrm{Ng}$ ): "Look [Antony MD] you know I was an employee of the company [Cleo] and [Cleo Chairman] was my chairman. Our clear understanding was that if you wanted me to do any secret stuff for you..."

Antony's MD : "[interrupts] What secret stuff? What was so secret about telling me [in advance] before the parachute thing blew up (Interview with Antony's MD, 22/12/1998)?”

As a result of the "Golden Parachute" incident, Antony's directors tried, albeit belatedly, to mount a rearguard action against Cleo's chairman. Whereas previously Cleo's chairman had won over supporters in both Antony and Cleo, he alienated most of the Antony board with his handling of the "Golden Parachute" incident. Antony's ED was particularly irked that he had not even been informed in advance of the story leaking in the press :

"Dear [Antony chairman]

[Antony MD] and I discussed the Straits Times and Business Times newspaper article on the proposal to give [Cleo chairman] the golden parachute in his service contract... The article seems to imply that consent has been given by our board and that Antony is the concerted party with [Cleo chairman]. Today's article in the Business Times confirms our initial fears. [Antony MD] said that he has not given consent either as a director of Antony or Cleo. I am not aware of this except from the newspapers and I do not know if $\mathrm{J}$ is aware of this (Memo to Antony's chairman, 8/06/1996)."

The board minutes of Antony and Cleo during this period suggest that Cleo's chairman paid no attention to Antony's concerns. How can one read the relative lack of discursive performances by Cleo's chairman? As Cleo's chairman had achieved his personal objective and had seized control of Cleo it appeared that he thereafter simply lost interest in performing publicly, a skill which he had carefully nurtured previously. Cleo's board minutes during the outcome stage were written up in a new terse, matter-of-fact style which contrasted with minutes during the transition stage which often gave a detailed, 
"blow-by-blow" account of board discussions. The change in writing style reflected the generally calmer tone of Cleo's board meetings once the chairman had taken absolute control. Consequently, in the outcome stage, there were less discursive performances recorded, and the minutes became less interesting from a narrative perspective. Perhaps the most notable consequence of the new style of board minutes was that there appeared no record of board members putting up any opposing view to Cleo's chairman once he had spoken and stated his views.

\section{Epilogue}

Ultimately, there was a price to pay for the Cleo chairman's failure to keep up his discursive performances as the discord between the chiefs at Antony and Cleo continued to simmer. The Cleo chairman's seemingly unassailable position was undone in a matter of weeks after Antony sold its controlling stake in Cleo without prior consultation with Cleo's chairman. While the sale might have been a predictable outcome of his victory, Cleo's chairman did not bargain for the uncertainty that resulted from Antony's sale to a son of the-then Indonesian President Suharto. All of Antony's representatives on Cleo's board, including the first author, resigned following the sale. A few weeks later Cleo's chairman himself sold out of Cleo. But he jumped without his parachute. Stalemate, or more precisely, double checkmate.

\section{The interpretative moment}

Story interpretation requires an answer to the deceptively simple question: "Why did things turn out the way they did?" In constructing our answer we will turn to the effective use of poetic tropes by the Cleo chairman. Our sensemaking can be further improved by exploring the deeper discursive and social structures in which both storyteller and audience were situated, and through which the very possibility of intentional communication is both enabled and constrained (cf. Heracleous and Hendry, 2000). In doing so we establish a difference between text and context. Indeed, not everything can be reduced to discourse and narrative, and the efficacy of the chairman's performances can be seen to depend on a clever exploitation of the interplay between discursive practice and social practice. 


\section{Poetic tropes}

In our story we have shown how the turbulence of organizational change presents situational opportunities for corporate actors to assert sectarian interests by trying to impose their story as the one others should live by. The Cleo chairman succeeded in moulding organizational events in a distinct and individual way through the use of poetic tropes which were reinforced through distinctive performances in the board room. Particular powerful tropes he employed were attribution of causal connection (linking various incidents as cause and effect), attribution of responsibility (determines whether an individual will be cast in the role of villain, victim or hero), and attribution of fixed qualities (juxtaposition of two people or situations whose qualities are meant to be exact opposites $)^{6}$. Poetic tropes were combined through story-work to generate complex narrative constructions out of simple events (viz. the three tables we presented earlier).

The tropes of attribution of blame and credit and attribution of responsibility are most evident in the Cleo chairman's astute development of his identity as corporate savior without equal, even leaving it to others to contribute narrative fragments underlining his experience and reputation (see table 1, narrative 2). This great experience was then successfully juxtaposed with the inexperience of turnaround situations and the "shortterm trader" reputation of the Antony chairman (cf. deprecating "John Wayne" rumours). Through opposition qualities become both fixed and exaggerated, thus legitimizing or delegitimizing respectively any future actions. The respective performances of the protagonists served to reinforce the effect of the poetic tropes used by the Cleo chairman.

The Cleo chairman was also very successful in representing actions and events as necessary rather than accidental or conditional. Establishing orderly sequences of causes and effect is a powerful means of organizing and rationalizing remembered experiences (Gabriel, 2000). The simple chain of causes and effects which appeared seamlessly linked together looked something like this: Cleo records its first ever operating loss; therefore we have to take drastic action/there is no time to waste, therefore I appoint three handpicked managers (whom had started work before the board approved the 
appointment); it is now time to bite the bullet with internal restructuring (subtext: ... so do not oppose my actions); if only we had been allowed to do this the company would have saved a lot of money (post-hoc legitimation, also see table 2, narrative 2). All the other directors could do once they had bought into the story was applaud the Cleo chairman.

\section{Discursive and social structures}

But why did the chairman's discursive performances have such a powerful and permanent grip over the Cleo and Antony board members? To further refine our answer we have to explore how particular storytelling performances draw from discursive structures of communicational legitimacy or appropriateness in local contexts. Individual narratives are always situated within specific social, cultural, and institutional discourses (Hardy and Phillips, 1999) and the efficacy of stories is inseparable from culturally and historically shared conventions about language and the hearing of stories (Atkinson and Coffey, 1997). Following the concept of the Ricœurian speech act, we treat the social context of production and reception as a resource for the creation and manifestation of meaning, not simply as a structural constraint on the possibility of meaning more structural approaches would suggest (cf. Heracleous and Hendry, 2000).

The key contextual clue in our story is the ethnic Chinese make-up of Cleo's directors. The efficacy of the chairman's performances depended upon the receptiveness of listeners to particular archetypal relationship-driven themes, chiefly patriarchal roleplaying and personal loyalty which, together with other relationship themes (e.g., filial piety), have served as an important overarching framework ("life orientation") for sociocultural behavior in Chinese societies (Tu, 1994, p.15). The selective use of Chinese themes proved to be an extremely effective rhetorical strategy which had strong legitimizing effects by representing sectional interests as universal and transmuting contradictions (cf. Wilkinson, 1996, p.439). Board members and managers rallied around their chairman after he successfully convinced them that, given his unmatched business reputation and commanding performances, he was best-suited to play the role of Cleo's patriarch. In appropriating the traditional, institutionalized role of a dominant sagepatriarch, any opposition or dissent could be construed as disloyal and hence morally 
unacceptable. The Singaporean context in which the discursive performances took place was fundamentally receptive to the appropriation of this authoritative organizational role (Haley and Low, 1998). This archetypal theme was so powerful in establishing a power base because it used actors' most deeply ingrained preconscious conceptions of the structuring of social processes, an observation not necessarily unique to the Singaporean context. Sköldberg (1994), for example, found in a Scandinavian context that "regardless of change problematic, organizations are liable rather to follow the dictates of narrative traditions than either 'objective' structures of problems and power, or demands of shared symbolisms (p.236)." In this sense "the world of fiction leads us to the heart of the real world of action (Ricœur, 1983, p.296)."

The formal, regulated setting of a board room setting imposes specific modes of discourse that senior organizational actors have to employ in order for their opinions and argumentations to be seen as legitimate and worth attention. The Cleo chairman, in establishing a "right" to the dominant discourse (through effective use of poetic tropes and exploiting archetypal themes) could effectively frame the strategies of action of other board members. Once a dominant discourse began to emerge, board members tried to translate it for their own needs and situate themselves within this discourse. In a sense, the chairman successfully crafted for himself an avuncular role beyond his executive role and other directors, even those who had initially opposed him, acknowledged that he was better suited to "save" Cleo, even if saving the company meant that the chairman got what he wanted by effectively denying Antony any further management involvement in its largest investment.

The above should not lead us to see storytelling as automatically dissolving facts. We do well to heed Keenoy et al.'s (1997) observation that much research on organizational discourse has been decidedly two-dimensional, in that it has tended to consider text and discursive practice but has ignored social practice. In our case study, Cleo's chairman used his hierarchical position to create an operating structure where newly appointed managers were personally loyal to him and he appropriated sole control of information flows, which ultimately allowed him to "have his way". This may seem nothing more 
than an application of "old fashioned" legitimate power. However, the chairman could only engage in these actions after establishing discursive legitimacy (cf. Hardy and Phillips, 1998) through the storytelling performances described above. Indeed, his formal power as a minority shareholder was far less than that of Antony's chairman as majority shareholder after the takeover. Even during the "implementation" stage the Cleo chairman's actions could have been undone by board colleagues of equally distinctive positional authority (e.g., key managerial appointments had to be approved by board directors), but the chairman headed off his opponents by further legitimizing his actions in carefully crafted discursive performances.

\section{Reflecting on our story}

This article has at its core a story. Whilst there exist some historical examples of academic papers where a story is central (e.g., Jermier, 1985; Hines, 1988), recently there has been a surge in such approaches. Often the story is accompanied by interpretation (Mintzberg and Westley, 2000; Rhodes, 2000; Watson, 2000), but this is not always the case (Akin, 2000; van Iterson, 2000). These contributions seem quite congruent with the sober and chastened approach to knowledge generation that Alvesson and Deetz (2000) see as typical of critical research: "These knowledges are 'accountable to an audience' rather than 'provable within a formal system'... A conversation should not prevent evaluation, critique and challenge, but be, generally speaking, open to the possibility that everything is less stable and clear-cut than it seems and is, therefore, open for discussion and reconsideration (p.135)." This approach chimes with Wittgenstein's warning against the danger of wanting to make fine distinctions. What we have rather to do is accept the everyday language-game and, "What's ragged should be left ragged" (Wittgenstein, 1980 - a remark that was identified as from c. 1944). This could be construed as complacency or resignation, but it might also be construed that the ragged is sometimes to be preferred to the smooth (Flathman, 2000). If this article is to act as inspiration for future research, we hope it does so in its adherence to the often rough but serviceable ground of day-today thinking and acting, plotting and practicing. We did what we could to clarify the story for ourselves and the reader, but we do not entertain the idea that the story's raggedness could or should be eliminated. 
Despite the professed emphasis of narrative approaches on organizations-embedded-inpractices and the unfolding of events over time (Czarniawska, 1997; Pentland, 1999; Tsoukas and Cummings, 1997), inadequate consideration of context and temporality has been a persistent issue in organizational discourse analysis (Heracleous and Hendry, 2000). Researchers often proceed to study the reified results of a construction process that is never revealed (Czarniawska, 1999; Alvesson and Deetz, 2000). The process of construction has been very much a central concern in this paper. In particular, using the experience and ongoing involvement of the principal author in board processes, we present an insider's view of how managers linguistically structure the world. Because managers are used to telling and hearing stories as perhaps the prime sensemaking device for managing people (Shaw et al., 1998; Weick, 1995, 1999), the narrative approach can be a powerful tool for bridging the traditional researcher-practitioner gap. Yet, we have no intention to tell managers how to restructure an organization or how to behave in the boardroom. Neither is there a need to provide law-like theories with their attractive elegance and highly glossed accounts, the usefulness of which remains very suspect (Czarniawska and Joerges, 1996). We simply wanted to tell a complex story of storytelling, with human actors busying themselves with plotting, performing, accounting for what they do, and thus producing reality as they know it. Our interpretation functions as a meta-account on the importance of storytelling and is meant to guide the sensemaking process of both managers-practitioners and academics-practitioners, but we certainly do not want to impose a "correct" reading.

It is a difficult challenge for authors-cum-storytellers to not privilege their point of view, and be self-reflexive about the ways in which they select textual fragments and recontextualise their meaning in a write-up. Whilst we do recognise the need for reflexivity, we are very reluctant to produce an "innovative" account to deal with this issue. The idea that reflexivity might come about as the result of some specific combination of techniques drawn from a set of standardized reflexive devices (such as including "the authors" in the text or establishing feedback loops with informants, e.g. see Boje et al. 1999) is unlikely to prove satisfactory because it pays little attention to the 
concept of reader and it retains a naive belief in the possibility of writing truer texts (De Cock, 2000). Woolgar (1988) suggested we therefore develop an understanding of a research text as an element in a reader-text community.

If we accept Woolgar's advice, it follows that this article is subject to the potential for multiple readings ${ }^{7}$. Any given reading may not be "the best", but it may be better at achieving particular effects than would be achieved by other types of readings (Rhodes, 2000). For example, whilst we have focused on stories and discourse in this article, readers with an interest in corporate governance may put different emphases. In the context of a paucity of field-based studies examining the behavior of, and relationships between, top managers and directors in organizations (Golden-Biddle and Hayagreeva, 1997; McNulty and Pettigrew, 1999), our account of behavioral dynamics in the boardroom offers "close-up" insights which these readers can reconstruct and connect differently to make them personally useful. There exists also only a limited body of field research conducted in companies located in the Pacific Rim (Kaghan et al., 1999), largely because of the difficulty of extracting primary source material from Asian managers about their organizations (Kim, 1997). Readers with an interest in Asian management practices, while not interested in narratives per se, may therefore find our story memorable and reconnect particular elements which they may find peculiar to the Asian environment (such as patriarchal role playing) in ways they find useful.

Finally, our story, whilst being contextually shaped by the Singapore environment, is nonetheless not confined to this particular environment. The role of storytelling as a powerful concept has been noted across cultural, temporal, and other boundaries (Gabriel, 2000; Goshal et al., 1999). Taking a recent European example, during our revision of this paper a different boardroom story emerged when the Financial Times reported on its front page the "Vodafone chief's £10m bonus" (FT, 20/06/2000). Vodafone’s board of directors approved the award of a $£ 10 \mathrm{~m}$ bonus to Chris Gent, the chief executive, as reward for organizing the company’s £113bn takeover of Mannesmann, only half of which would be subject to performance conditions ${ }^{8}$. In a further article, "A real sporting 
gent with a nice line, too, in storytelling” (FT, 20/06/2000, p.30), Gent's skill as "raconteur" was singled out as "an important deciding factor" in gaining control of Mannesmann. Given our boardroom-centered approach in this paper, what is of additional interest is the way Vodafone's chief executive might have deployed his storytelling skills to persuade fellow directors (including members of the powerful remuneration committee) to go out of their way to make a vast payment to him at a time when there seemed no apparent need to do so and then to have to defend their actions publicly. Whilst we are unlikely to learn how this happened unless a board participant speaks out publicly, the FT's report of Gent's storytelling skills emphasizes the importance of discursive performances in enabling senior corporate officers to "get their own way". 


\section{Table 1: Competing Narratives "Transition” Stage}

\begin{tabular}{|c|c|c|}
\hline $\begin{array}{l}\text { Narrative 1: Dominant } \\
\text { CLEO'S OFFICIAL } \\
\text { PUBLIC STORY: }\end{array}$ & $\begin{array}{l}\text { Narrative 2: Emerging } \\
\text { CLEO CHAIRMAN'S } \\
\text { STORY (INTERNAL) }\end{array}$ & $\begin{array}{l}\text { Narrative 3: Competing } \\
\text { for Dominance } \\
\text { ANTONY'S OFFICAL } \\
\text { PUBLIC STORY: }\end{array}$ \\
\hline $\begin{array}{l}\text { Incremental change process } \\
\text { controlled by Cleo's } \\
\text { management }\end{array}$ & $\begin{array}{l}\text { Building up Cleo } \\
\text { chairman's reputation }\end{array}$ & $\begin{array}{l}\text { Antony controls its } \\
\text { subsidiary and manages its } \\
\text { restructuring }\end{array}$ \\
\hline $\begin{array}{l}\text { Stock Exchange releases convey } \\
\text { impression of an organized } \\
\text { change program controlled by } \\
\text { Cleo's management: } \\
\text { "The [Cleo] Group has } \\
\text { successfully undertaken an } \\
\text { extensive program to review and } \\
\text { restructure its operations to be } \\
\text { more competitive (Cleo } \\
\text { announcement of } 1996 \text { results, } \\
\text { 29/03/1997) }\end{array}$ & $\begin{array}{l}\text { Cleo chairman's performances at } \\
\text { board meetings develops his own } \\
\text { reputation as a corporate savior } \\
\text { without equal: } \\
\text { "[Cleo chairman's] experience } \\
\text { was than an engineering } \\
\text { operation like Cleo was } \\
\text { worthwhile because of the quality } \\
\text { of its staff" (Antony board } \\
\text { minutes, 13/04/1995) }\end{array}$ & $\begin{array}{l}\text { Antony's public documents } \\
\text { suggest that Antony is } \\
\text { orchestrating Cleo's restructuring } \\
\text { process: } \\
\text { "Upon completion of the offer, } \\
\text { Antony will undertake a detailed } \\
\text { review of the operations and } \\
\text { business of the Cleo group with } \\
\text { the assistance of the current } \\
\text { management of Cleo" (Antony } \\
\text { takeover circular, 09/03/1995) }\end{array}$ \\
\hline $\begin{array}{l}\text { Cleo's public texts (reports, } \\
\text { circulars) suggest slow but } \\
\text { controlled progress: } \\
\text { "1995 has proved a difficult } \\
\text { year... but the [Cleo] Group has } \\
\text { managed to make substantial } \\
\text { progress in its reorganization } \\
\text { efforts through proper planning } \\
\text { and staff Cupertino (Chairman's } \\
\text { statement, Cleo } 1995 \text { Annual } \\
\text { Report, p.5) }\end{array}$ & $\begin{array}{l}\text { Cleo chairman's experience and } \\
\text { reputation story: } \\
\text { "As [Cleo Chairman] has all the } \\
\text { credentials for the job, Mr. T said } \\
\text { the least the directors could do } \\
\text { was to offer him the board's full } \\
\text { support" (Antony board minutes, } \\
\text { 12/04/1995) }\end{array}$ & $\begin{array}{l}\text { Antony board minutes suggest } \\
\text { Antony wanted to slow down the } \\
\text { pace of change: } \\
\text { "We should not commit ourselves } \\
\text { to something we cannot get out of } \\
\text { later" } \\
\text { "[Antony] chairman said we must } \\
\text { continue with the original plan to } \\
\text { move the company forward. He } \\
\text { was against giving any card } \\
\text { blanch [sic] to run Cleo" (Antony } \\
\text { board minutes, 15/02/1995) }\end{array}$ \\
\hline $\begin{array}{l}\text { Cleo-sourced staff figures } \\
\text { showed generally low staff } \\
\text { turnover throughout the } \\
\text { restructuring which supported the } \\
\text { "professionally-managed" } \\
\text { success declared by Cleo's } \\
\text { management. }\end{array}$ & $\begin{array}{l}\text { Cleo's senior managers support } \\
\text { deprecating rumors about } \\
\text { Antony's chairman: } \\
\text { "[Divisional Directors] made } \\
\text { [computer] printouts and put this } \\
\text { John Wayne cowboy picture of } \\
\text { [Antony Chairman] on the tables. } \\
\text { I think they put [up] six or seven } \\
\text { pictures on a stand and one } \\
\text { lunchtime some of the boys took } \\
\text { out a water gun and they all tried } \\
\text { [in turn] to shoot down all the } \\
\text { pictures in one go" (Cleo FC } \\
\text { interview, 15/02/1999) }\end{array}$ & $\begin{array}{l}\text { Professional treatment of media: } \\
\text { “Antony's chairman attended [an } \\
\text { arranged meeting with analysts] } \\
\text { and participated in the question } \\
\text { and answer session [on the } \\
\text { restructuring] (JM Sassoon } \\
\text { stockbrokers' report, June 1996) }\end{array}$ \\
\hline
\end{tabular}




\section{Table 2: Competing Narratives "Implementation" Stage}

\begin{tabular}{|c|c|c|}
\hline $\begin{array}{l}\text { Narrative 1: Dominant } \\
\text { CLEO'S OFFICIAL } \\
\text { PUBLIC STORY }\end{array}$ & $\begin{array}{l}\text { Narrative 2: Strengthening } \\
\text { CLEO CHAIRMAN'S } \\
\text { STORY (INTERNAL) }\end{array}$ & $\begin{array}{l}\text { Narrative 3: Weakening } \\
\text { ANTONY'S OFFICIAL } \\
\text { PUBLIC STORY }\end{array}$ \\
\hline $\begin{array}{l}\text { Cleo's management } \\
\text { orchestrates radical and } \\
\text { authoritative response to } \\
\text { poor financial results }\end{array}$ & $\begin{array}{l}\text { Cleo Chairman is taking } \\
\text { personal control of Cleo }\end{array}$ & $\begin{array}{l}\text { Antony tries vainly to } \\
\text { control Cleo's managers }\end{array}$ \\
\hline $\begin{array}{l}\text { Cleo public announcements: } \\
\text { "The board announces an } \\
\text { operating loss of } \$ 4.238 \text { million } \\
\text { for the six months ended } 30^{\text {th }} \\
\text { June of } 1995 \ldots \text { this represents a } \\
353 \% \text { decline from the previous } \\
\text { period. In response to [this } \\
\text { unprecedented] loss, the company } \\
\text { will undertake immediate } \\
\text { measures to reverse the decline" } \\
\text { (Cleo announcement, } \\
\text { 30/09/1995) }\end{array}$ & $\begin{array}{l}\text { Domineering performance by } \\
\text { Cleo chairman: } \\
\text { "Chairman said that he would like } \\
\text { to propose the names of } 3 \\
\text { executives as board directors with } \\
\text { immediate effect and that he } \\
\text { wished to introduce them [to the } \\
\text { meeting]" } \\
\text { "Chairman said that it was now } \\
\text { necessary to bite the bullet with } \\
\text { the internal restructuring." (Cleo } \\
\text { board minutes, 14/10/1995) }\end{array}$ & $\begin{array}{l}\text { Antony public announcements } \\
\text { suggest "normal upgrading" at } \\
\text { Cleo: } \\
\text { "Since Cleo was in a fast-moving } \\
\text { industry... should it not follow } \\
\text { that Antony should contribute } \\
\text { whatever expertise it could to } \\
\text { help Cleo stay ahead of the game" } \\
\text { (Antony ED, "Business Times", } \\
\text { 16/02/1996). }\end{array}$ \\
\hline $\begin{array}{l}\text { Antony board support for Cleo: } \\
\text { "The board supports Cleo's } \\
\text { restructuring efforts which should } \\
\text { now be completed as soon as } \\
\text { possible (Antony board minutes, } \\
\text { 29/09/1995) }\end{array}$ & $\begin{array}{l}\text { Antony chairman's poor } \\
\text { discursive performances in } \\
\text { Antony board meetings weakens } \\
\text { his board support and strengthens } \\
\text { that of Cleo's chairman }\end{array}$ & $\begin{array}{l}\text { Antony management attempts to } \\
\text { control Cleo's restructuring: } \\
\text { "[Antony chairman] believed } \\
\text { Cleo's operating policies had to } \\
\text { be brought into line with } \\
\text { Antony's... It was bad practice to } \\
\text { let subsidiaries dictate policy to } \\
\text { the Group (Antony board } \\
\text { minutes, 29/09/1995) }\end{array}$ \\
\hline $\begin{array}{l}\text { Tight internal Cleo management } \\
\text { and policy implementation: } \\
\text { "stick" of tightened expenditure } \\
\text { policy with increased reporting } \\
\text { and expenditure claims procedure } \\
\text { (Cleo board minutes, 28/09/1995) } \\
\text { versus- } \\
\text { "carrot" of extended ESOS } \\
\text { (employees share option scheme) } \\
\text { predicated on profits, long service } \\
\text { and "personal achievements" } \\
\text { (Cleo Group Share Option } \\
\text { Scheme, 03/05/1995) }\end{array}$ & $\begin{array}{l}\text { Restricted information channeled } \\
\text { only through Cleo management } \\
\text { hierarchy: } \\
\text { "It was such a big deal to get } \\
\text { anything from the company } \\
\text { [Cleo]. I just didn't understand all } \\
\text { these games you people were } \\
\text { playing (Antony MD interview, } \\
22 / 12 / 1998 \text { ). }\end{array}$ & $\begin{array}{l}\text { Antony management's attempts to } \\
\text { make sense of Cleo's radical } \\
\text { measures: } \\
\text { "[Group Finance Director] was } \\
\text { asked to investigate and report } \\
\text { how [Cleo's] major competitors } \\
\text { accounted in their books for } \\
\text { work-in-progress [to explain } \\
\text { Cleo's profit fluctuation]" Antony } \\
\text { board minutes, 29/09/1995) }\end{array}$ \\
\hline
\end{tabular}


Table 3: Competing Narratives "Outcome" Stage

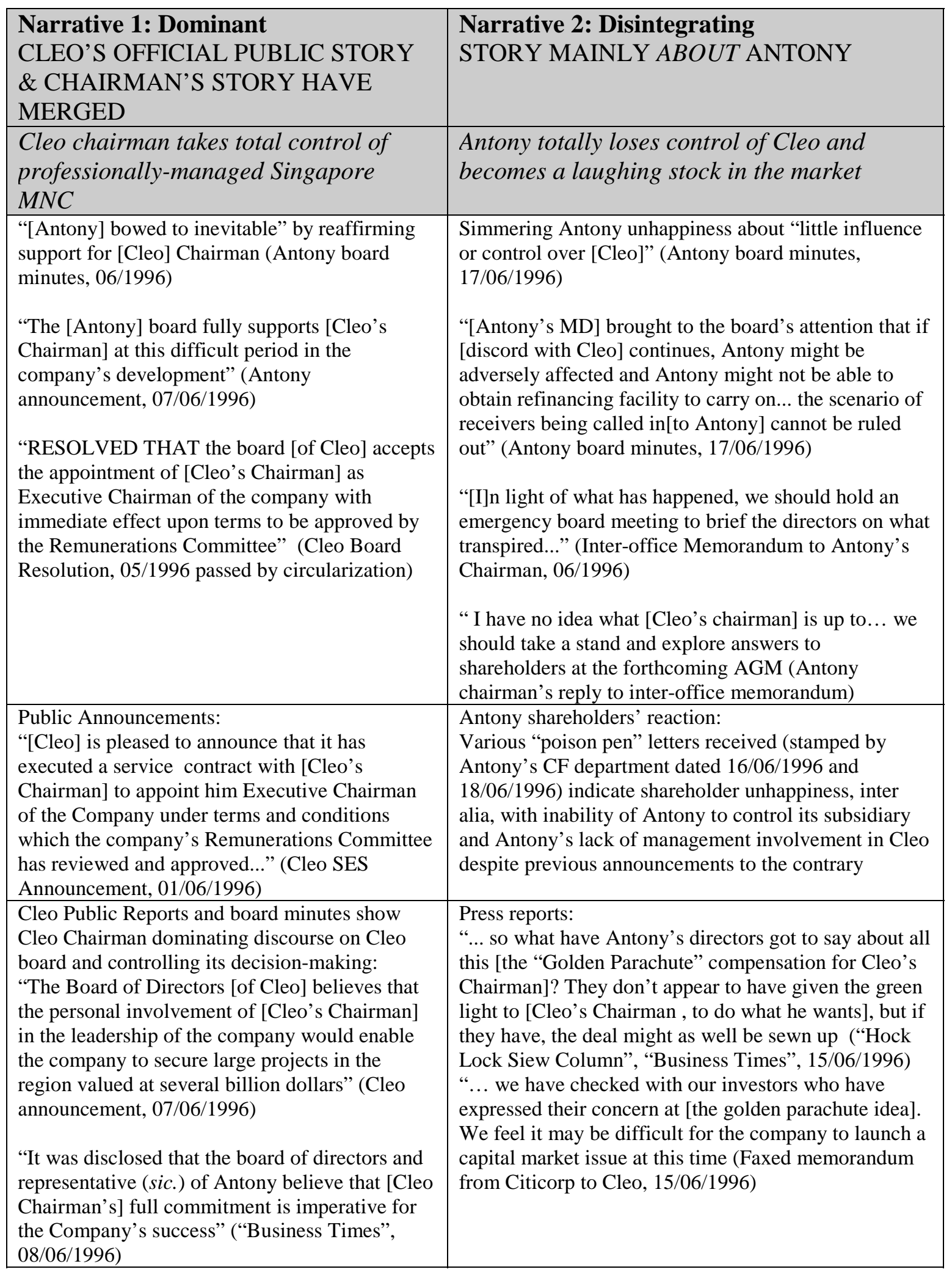




\section{REFERENCES}

AKIN, G. (2000). 'Learning about work from Joe Cool'. Journal of Management Inquiry, 9, 57-61.

ALVESSON, M. and DEETZ, S. (2000). Doing Critical Management Research. London: Sage.

ATKINSON, P., and COFFEY, A. (1997). 'Analysing Documentary Realities'. In Silverman D. (Ed.), Qualitative Research: Theory, Method and Practice. London: Sage, 45-62.

BARRETT, F. J., THOMAS, G. F., and HOCEVAR, S. P. (1995). 'The central role of discourse in large-scale change: a social construction perspective'. Journal of Applied Behavioral Science, 31, 352-372.

BARRY, D. (1996). 'Artful inquiry: a symbolic constructivist approach to social science research'. Qualitative Inquiry, 2, 411-438.

BARRY, D., and ELMES, M. (1997). 'Strategy retold: toward a narrative view of strategic discourse'. Academy of Management Review, 22, 429-452.

BOJE, D. M. (1991). 'The storytelling organization: a study of story performance in an office-supply firm'. Administrative Science Quarterly, 36, 106-126.

BOJE, D. M. (1995). 'Stories of the storytelling organization: a postmodern analysis of Disney as "Tamara-Land"'. Academy of Management Journal, 38, 997-1035.

BOJE, D. M. (1998). 'The postmodern turn form stories-as-objects to stories-in-context methods'. 1998 Research Methods Forum No.3, 1-4.

(http://www.aom.pace.edu/rmd/1998_forum_postmodern_stories.html)

BOJE, D. M., LUHMAN, J. T., and BAACK, D. E. (1999). 'Hegemonic stories and encounters between storytelling organizations'. Journal of Management Inquiry, 8, 340360.

BOLAND, R. J., and TENKASI, R. V. (1995). 'Perspective making and perspective taking in communities of knowing'. Organization Science, 6, 350-372.

BOURDIEU, P. (1991). Language and Symbolic Power. Cambridge: Polity.

BOYCE, M. E. (1996). 'Organizational story and storytelling: a critical review'. Journal of Organizational Change Management, 9, 5, 5-26.

BROWN, A. D. (2000). 'Making sense of inquiry sensemaking'. Journal of Management Studies, 37, 45-75. 
BROWN, A. D., AND JONES, M. (2000). 'Hounourable members and dishonourable deeds: sensemaking, impression management and legitimation in the 'Arms to Iraq Affair". Human Relations, 53, 655-689.

BRUNER, J. (1986). Actual Minds, Possible Worlds. Cambridge (MA): Harvard University.

BRUNER, J. (1990). Acts of Meaning. Cambridge: Cambridge University.

BURKITT, I. (1998). 'Bodies of knowledge: beyond Cartesian views of persons, selves and mind'. Journal for the Theory of Social Behavior, 28, 63-82.

CALAS, M. B., and SMIRCICH, L. (1999). 'Past postmodernism? Reflections and tentative directions'. Academy of Management Review, 24, 649-671.

CASEY, C. (1995). Work, Self and Society After Industrialism. London: Routledge.

COFFEY, A., and ATKINSON, P. (1996). Making Sense of Qualitative Data: Complementary Research Strategies. London: Sage.

CZARNIAWSKA, B. (1997). Narrating the Organization: Dramas of Institutional Identity. Chicago: University of Chicago Press.

CZARNIAWSKA, B. (1998). A Narrative Approach to Organization Studies. London: Sage.

CZARNIAWSKA, B. (1999). Writing Management: Organization Theory as a Literary Genre. Oxford: Oxford University.

CZARNIAWSKA, B., and JOERGES, B. (1996). 'Travels of ideas'. In Czarniawska, B. and Sevón, G. (Eds), Translating Organizational Change. Berlin: de Gruyter, 13-48.

DE COCK, C. (2000). 'Reflections on fiction, representation and organization studies: an essay with special reference to the work of Jorge Luis Borges'. Organization Studies, 21, 589-609.

DEVAULT, M. L. (1990). 'Novel readings: the social organization of interpretation'. American Journal of Sociology, 95, 887-921.

FISHER, W. R. (1985). 'The narrative paradigm: an elaboration'. Communication Monographs, 52, 347-367. 
FLATHMAN, R. E. (2000). 'Wittgenstein and the social sciences: critical reflections concerning Peter Winch's interpretations and appropriations of Wittgenstein's thought'. History of the Human Sciences, 13, 2,1-15.

GABRIEL, Y. (2000). Storytelling in Organizations: Facts, Fictions, and Fantasies. London: Sage.

GABRIEL, Y. (1998). 'Same old story or changing stories? Folkloric, modern and postmodern mutations'. In Grant, D., Keenoy, T. and Oswick C. (Eds), Discourse and Organization. London: Sage, 84-103.

GEPHART, R. P. (1978). 'Status degradation and organizational succession: an ethnomethodological approach'. Administrative Science Quarterly, 23, 553-581.

GEPHART, R. P. (1993). 'The textual approach: risk and blame in disaster sensemaking'. Academy of Management Journal, 36, 1465-1514.

GOLDEN-BIDDLE, K., and HAYAGREEVA, R. (1997). 'Breaches in the boardroom: organizational identity and conflicts of commitment in a nonprofit organization'. Organization Science, 8, 593-611.

GOLDEN-BIDDLE, K., and LOCKE, K. (1997). Composing Qualitative Research. Thousand Oaks: Sage.

GHOSHAL, S., BARTLETT, C.A., and MORAN, P. (1999). 'A new manifesto for management'. Sloan Management Review, Spring, 9-20.

HALEY, U.C.V. and LOW, L. (1998). 'Crafted culture: governmental sculpting of modern Singapore and effects on business environments'. Journal of Organizational Change Management, 11, 530-553.

HARDY, C., and CLEGG, S. R. (1996). 'Some dare call it power'. In Clegg, S.R., Hardy, C. and Nord, W.R. (Eds), Handbook of Organization Studies. London: Sage, 622-641.

HARDY, C., and PHILLIPS, N. (1998). 'Strategies of engagement: lessons from the critical examination of collaboration and conflict in an interorganizational domain'. Organization Science, 9, 217-230.

HARDY, C., and PHILLIPS, N. (1999). 'No joking matter: discursive struggle in the Canadian refugee system'. Organization Studies, 20, 1-24.

HERACLEOUS, L, and HENDRY, J. (2000). 'Discourse and the study of organization: Toward a structurational perspective'. Human Relations, 53, 1251-1286.

HINES, R. (1988). 'Financial accounting: in communicating reality, we construct reality'. Accounting, Organizations and Society, 13, 251-261. 
ISER, W. (1989). Prospecting: From Reader Response to Literary Anthropology. Baltimore: Johns Hopkins.

JERMIER, J. (1985). "'When the sleeper wakes": a short story extending themes in radical organization theory'. Journal of Management, 11, 67-80.

KEENOY, T., OSWICK, C., and GRANT, D. (1997). 'Organizational discourses: text and context'. Organization, 4, 147-158.

KIM, L. S. (1997). Imitation to Innovation: The Dynamics of Korea's Technological Learning. Boston (MA): Harvard Business School.

MACINTYRE, A. (1985, 2nd ed.). After Virtue: A Study in Moral Theory. London: Duckworth.

MARCH, J. G. (1996). 'Continuity and change in theories of organizational action'. Administrative Science Quarterly, 41, 278-287.

MCNULTY, T., AND PETTIGREW, A. (1999). 'Strategists on the board'. Organization Studies, 20, 47-74.

MINTZBERG, H., AND WESTLEY, F. (2000). 'Sustaining the institutional environment'. Organization Studies, 21, 71-94.

OAKES, L. A., TOWNLEY, B., and COOPER, D. J. (1998). 'Business planning as pedagogy: language and control in a changing institutional field'. Administrative Science Quarterly, 43, 257-292.

PENTLAND, B. T. (1999). 'Building process theory with narrative: from description to explanation'. Academy of Management Review, 24, 711-724.

PHILLIPS, N., AND HARDY, C. (1997). 'Managing multiple identities: discourse, legitimacy and resources in the UK refugee system'. Organization, 4, 159-185.

PRIOR, L. (1997). 'Following in Foucault's footsteps: text and context in qualitative research'. In Silverman, D. (Ed), Qualitative Research: Theory, Method and Practice. London: Sage, 63-79.

PUTNAM, L. L., PHILLIPS, N. and CHAPMAN, P. (1996). 'Communication in organizations'. In Clegg, Stewart R., Hardy, Cynthia and Nord, Walter N. (Eds), Handbook of Organization Studies. London: Sage, 375-408.

RAPPAPORT, J. (1993). 'Narrative studies, personal stories, and identity transformation in the mutual help Context'. Journal of Applied Behavioral Science, 29, 239-256. 
RHODES, C. (2000). 'Reading and writing organizational lives'. Organization, 7, 7-29.

RICEEUR, P. (1983). 'The narrative function'. In J. B. Thompson (ed.), Paul Ricoeur, Hermeneutics and the Human Sciences: Essays on Language, Action and Interpretation. Cambridge: Cambridge University Press, 274-296.

RIESSMAN, C. K. (1993). Narrative Analysis. London: Sage.

RORTY, R. (1991). Essays on Heidegger and Others: Philosophical Papers Volume 2. Cambridge: Cambridge University Press.

SHAW, G., BROWN, R., and BROMILEY, P. (1998, May-June). 'Strategic stories: how $3 \mathrm{M}$ is rewriting business planning'. Harvard Business Review, 50, 41-50.

TAYLOR, C. (1985/1995). Philosophy and the Human Sciences: Philosophical Papers 2. Cambridge: Cambridge University Press.

TSOUKAS, H., and CUMMINGS, S. (1997). 'Marginalization and recovery: the emergence of Aristotelian themes in organization studies'. Organization Studies, 18, 655683.

TU, W. M. (1994). The Living Tree: The Changing Meaning of Being Chinese Today. Stanford: Stanford University Press.

VAN ITERSON, A. (2000). 'Organizational doom and resurrection'. Organization Studies, 21, 95-102.

VAN MAANEN, J. (1998). 'Different strokes: qualitative research in the Administrative Science Quarterly from 1956 to 1996'. In Van Maanen, J. (Ed), Qualitative Studies of Organizations. London: Sage, ix-xxxii.

WATSON, T.J. (2000). 'Ethnographic fiction science: making sense of managerial work and organizational research processes with Caroline and Terry'. Organization, 7, 489-510.

WATSON, T.J., and HARRIS, P. (1999). The Emergent Manager. London: Sage.

WEICK, K. (1995). Sensemaking in Organizations. London: Sage.

WEICK, K. E. (1999). 'That's moving: theories that matter'. Journal of Management Inquiry, 8, 134-142.

WICKS, A. C., and FREEMAN, E. R. (1998). 'Organization studies and the new pragmatism: positivism, anti-positivism, and the search for ethics'. Organization Science, 9, 123-140. 
WILKINSON, B. (1996). 'Culture, institutions and business in East Asia'. Organization Studies, 17, 421-447.

WOOLGAR, S. (1988). 'Reflexivity is the ethnographer of the text'. In Woolgar S. (ed.), Knowledge and Reflexivity: New Frontiers in the Sociology of Bnowledge. London: Sage, 14-36.

WITTGENSTEIN, L. (1980). Culture and Value. Chicago: University of Chicago Press. 
Notes:

1 "The Straits Times", 03/03/1995; fictitious names have been substituted for actual company names. In order to preserve the relative anonymity of the subject companies we have also changed the original dates of publication of all texts while preserving the chronological order and time lapses between texts. For example, original documents from 03/03/1985 and 01/01/1986 could be referred to as 03/06/1995 and 01/04/1996 in our analysis. However, interview dates have remained unchanged.

${ }^{2}$ For an alternative view, see Gabriel $(1998,2000)$ who suggested that by obliterating distinctions between stories and other types of texts and narratives, stories lose precisely the power they are meant to possess, namely the power to generate and sustain meanings: "Storytelling is an art of weaving, of constructing, the product of intimate knowledge. It is a delicate process, a process that can easily break down, failing to live up to its promise, disintegrating into mere text (Gabriel, 2000, p.1)."

${ }^{3}$ As one $3 \mathrm{M}$ manager recently commented: "Stories are a habit of mind at $3 \mathrm{M}$, and it's through them - through the way they make us see ourselves and our business operations in complex, multidimensional forms - that we're able to discover opportunities for strategic change (in Shaw et al., 1998, p. 42)."

${ }^{4}$ Cleo's share price steadily appreciated through the "implementation" stage of restructuring (where it had languished unimpressively during the "transition" phase): from a low of S\$1.30 in September 1995 (shortly after the start of the "implementation" stage) it reached a high of $\mathbf{S} \$ 1.88$ on the eve of the "Golden Parachute" incident in June 1996, which was over $30 \%$ above the previous financial year's average share price. It appeared that Cleo's shareholders were impressed with the company's management and particularly its chairman who featured regularly in Cleo's press releases and newspaper articles.

${ }^{5}$ A new narrative developed from within Cleo, but it proved unable to mobilize adequate support to become as dominant as the chairman's story. This was despite the fact that the internal narrative was well planned and there seemed to be latent unhappiness, especially among Cleo's longer serving staff, about the way Cleo had become "bureaucratic" and impersonal.

${ }^{6}$ Gabriel (2000, p.34-42) gives an excellent overview of poetic tropes.

${ }^{7}$ Literary scholars have long accepted that readers always complete novels on their own terms. Reader-response theory (Iser, 1989) criticizes earlier theories that argued that the meaning of the text lay solely in its author's intentions or that meaning was to be found in the text alone. Readers place themselves in the text and then draw on a stock of knowledge about the world in order to complete the narrative, filling in details that are necessary for understanding but not explicit in the text, thus becoming active constructors of meaning (DeVault, 1990). Meaning is created in the interaction among author, text, and reader.

${ }^{8}$ Shareholders were reported to be angry: "Some called it a 'staggering' payment for a deal whose merits are yet unproven (FT, 20/06/2000, p.30)." They were unhappy that payment of half the $£ 10 \mathrm{~m}$ bonus in cash with no strings attached seemed to reward dealmaking as such rather than shareholder value creation. Vodafone's board subsequently agreed to restructure payment of the cash element of the bonus to better 
reflect the payee's future performance (FT, 22-23/07/2000). "Vodafone said: 'We hope this gesture - whereby Chris will be seen to put the vast majority of his bonus cash into Vodafone shares - will be well received by shareholders' (FT, 25/07/2000, p.25)." 